\title{
Program Kemitraan Masyarakat (PKM) Guru SMA di Kota dan Kabupaten Bandung dalam Kegiatan Pengolahan Data Berbasis E-Learning
}

\author{
Jusep Saputra ${ }^{1}$, Thesa Kandaga², Anggoro Ari Nurcahyo ${ }^{3}$ \\ 1,2,3 Universitas Pasundan
}

\begin{tabular}{|c|c|}
\hline ARTICLE INFO & ABSTRACT \\
\hline $\begin{array}{l}\text { Article History: } \\
\text { Received 11.09.2018 } \\
\text { Received in revised } \\
\text { form 15.11.2018 } \\
\text { Accepted 03.12.2018 } \\
\text { Available online } \\
\text { 26.12.2018 }\end{array}$ & $\begin{array}{l}\text { The purpose of the Subject Teachers Consultation (STC) is that they are able to } \\
\text { support teacher competencies. The STC included in the Community Partnership } \\
\text { Program (CPP) is the Bandung and City Mathematics STC. Problems with both } \\
\text { partners are: (1) Understanding of some teachers in collecting data according to } \\
\text { the formulation of research problems is still lacking, (2) Teachers do not know e- } \\
\text { learning applications that use video conferencing. (3) Some teachers in processing } \\
\text { research data with SPSS are still lacking, (4) some teachers have not been skilled in } \\
\text { making scientific articles. The two partners' solution-resolution procedures will be } \\
\text { carried out by the team are training, guidance, and accompaniment. CPP was } \\
\text { attended by } 14 \text { Mathematics Teachers from the City of Bandung, and } 17 \\
\text { Mathematics Teachers The first meeting resulted in the following conclusions: (1) } \\
\text { The quality of CPP in formulating problems, testing instruments, using SPSS } \\
\text { features, and video conferencing was conducted very good, (2) The abilities of } \\
\text { teachers to understand, master, and train in making either test or non-test research } \\
\text { instruments are in a pretty good category, (3) t The teacher's ability to input data } \\
\text { according to data or the scale of the data is in a good category, (4) The teacher's } \\
\text { ability to use video conferencing and guidance in doing the work is in good } \\
\text { category, 5) The ability to teach research data with SPSS; analyze, and interpret } \\
\text { research data in the good category, (6) The scientific ability is in a good enough } \\
\text { category. }\end{array}$ \\
\hline
\end{tabular}

Keywords: Data Processing Activities, E-Learning. cited. ๑ 2018 Jusep Saputra, Thesa Kandaga, Anggoro Ari Nurcahyo.

\section{PENDAHULUAN}

Musyawarah Guru Mata Pelajaran (MGMP) yaitu organisasi non-struktural berdasarkan Peraturan Pemerintah RI No.38/1994. Menurut panduan yang dipublish Direktorat Jenderal Pendidikan Dasar dan Menengah, “MGMP mempunyai lima tujuan: (1) Mendorong guru untuk meningkatkan kemampuan dan keterampilan mereka dalam merencanakan, melaksanakan serta mengevaluasi kegiatan belajar dan mengajar; (2)

${ }^{1}$ Corresponding author: Program Studi Pendidikan Matematika, FKIP Universitas Pasundan; Jl. Tamansari No 6-8, Bandung; Email: jusepsaputrapmat@unpas.ac.id. 
Wadah untuk merundingkan masalah yang dihadapi para guru dalam melaksanakan kewajiban sehari-hari mereka dan untuk mencari pemecahan yang sesuai dengan karakteristik mata pelajaran yang bersangkutan,guru,kondisi sekolah,dan masyarakat; (3) Memberi kesempatan bagi guru untuk berbagi informasi dan pengalaman mengenai pelaksanaan kurikulum,serta untuk mengembangkan sains dan teknologi; (4) Menyediakan kesempatan bagi para guru untuk menyampaikan pendapat mereka pada pertemuan MGMP sehingga meningkatkan kemampuan mereka; (5) Membangun kerjasama dengan lembaga-lembaga lain untuk menciptakan proses belajar mengajar yang kondusif,efektif,dan menyenangkan".

Salah satu tujuan tersebut diantaranya memberi kesempatan bagi guru untuk mengembangkan sains dan teknologi. Tujuan tersebut akan tercapai jika guru-guru terampil dan terbiasa menggunakan aplikasi produk teknologi dan mampu meningkatkan serta mengembangkan diri melalui berbagai kegiatan yang mampu menunjang kemampuan tersebut. Salah satu kegiatan yang dilakukan adalah mengikuti kegiatan pengembangan diri melalui Program Kemitraan Masyarakat (PKM) dengan LPTK seperti Universitas Pasundan.

Pada era revolusi industri 4.0 sekarang ini sudah jamannya memasuki dunia online, internet sudah menguasai kehidupan akan tetapi hal tersebut bisa berdampak (+) atau (), sehingga sejauh mana pendidik mengadposi teknologi tersebut untuk berbuat hal baik dan berguna untuk masyarakat umumnya dan peserta didik khususnya. Salah satu penggunaan internet yang positif adalah pembelajaran online melalui e-learning.

Banyak pakar pendidikan memberikan definisi mengenai e-learning, seperti yang dipaparkan oleh Thompson, et al. (Supianti, 2018), berikut ini, E-learning is an instructional content or learning experiences delivered or enabled by electronic technology. Kemudian Thompson juga menyebutkan kelebihan e-learning yang dapat memberikan fleksibilitas, interaktivitas, kecepatan, visualisasi melalui berbagai kelebihan dari masing-masing teknologi.

Pemanfaatan e-learning, selain sebagai upaya mengatasi permasalahan teknis pembelajaran (media pembelajaran), juga sebagai upaya menjawab masalah substansial pembelajaran (sumber ajar) (Saputra, 2017: 118). Dalam proses pembelajarannya, dimungkinkan adanya pengembangan diri peserta didik untuk bisa belajar mandiri tanpa adanya batasan jarak dan waktu sehingga bisa menumbuhkan kemandirian setelah belajar berkali-kali melalui e-learning, baik kompetensi kognitif maupun afektif dan tumbuhnya kreativitas para stakeholder pendidikan (Yaniawati, 2010).

Selain itu, publikasi karya tulis ilmiah pun sudah memasuki sistem online. Untuk melakukan publikasi tentunya harus ada artikel ilmiah dari hasil penelitian. Akan tetapi beberapa guru jarang melakukan penelitian karena kesulitan dalam proses pengolahan datanya. Dari beberapa permasalahan tadi, pembelajaran e-learning dan pengolahan data tersebut dirasakan sulit diikuti oleh beberapa guru.

Berdasarkan hasil survei terhadap guru matematika SMAN di Kota dan Kabupaten Bandung diperoleh hasil bahwa beberapa guru belum mengetahui SPSS yang bermanfaat dalam penelitian, pemahaman beberapa guru dalam mengumpulkan data sesuai rumusan masalah penelitian masih kurang, beberapa guru belum mengenal aplikasi e-learning yang menggunakan video converence, pemahaman beberapa guru dalam mengolah data penelitian dengan SPSS masih kurang, pemahaman beberapa 
guru dalam menganalisis dan menginterpretasi data penelitian masih kurang, eberapa guru belum terampil dalam membuat artikel ilmiah.

Hal tersebut sesuai dengan hasil pengabdian yang dilakukan oleh Yaniawati (2017: 2) bahwa "sebagian besar guru sudah terampil dalam menggunakan komputer dan internet terutama guru-guru yang masih muda. Akan tetapi, mereka belum terbiasa menggunakan e-learning sehingga perlu adanya pelatihan tersendiri dalam menggunakan e-learning".

SPSS adalah software pengolahan data statistik dengan penggunaan yang mudah (Andi, 2010: 2). Dengan demikian, sayang sekali jika guru-guru tidak memanfaatkan SPSS ini untuk penelitian. Selain itu, e-learning yang menggunakan video converence (vicon) sangat bermanfaat, karena dengan bantuan internet melalui vicon kita bisa belajar dimanapun dan kapanpun tanpa mengenal batasan jarak dan waktu.

Hal tersebut sesuai dengan fakta bahwa pembelajaran yang memanfaatkan TIK ini sejalan dengan kurikulum 2013 yang sedang diimplementasikan di Indonesia sekarang ini. Teknologi dimanfaatkan untuk efektivitas dan efisiensi proses pembelajaran, dan penelitian sehingga mendorong para guru dalam mengembangkan pembelajaran dan melaksanakan penelitian. Oleh karena itu tridharma yaitu pendidikan dan penelitian dapat dilakukan dengan banyaknya guru yang melakukan hal tersebut. Dengan demikian Program Kemitraan Masyarakat ini adalah program membantu guru dalam mengimplementasikan kurikulum 2013, yaitu penerapan TIK dalam pembelajaran dan penelitian.

\section{METODE PELAKSANAAN}

Metode yang dilakukan dalam mengatasi permasalah-permasalahan guru tersebut adalah dengan memberikan pelatihan atau training, bimbingan, dan pendampingan kepada para guru. Pelatihan dilakukan dengan melakukan pertemuan secara langsung melalui tatap muka (face to face) dengan para guru.

Setelah diadakan pelatihan, dilanjutkan dengan bimbingan dan pendampingan. Bimbingan dan pendampingan dilakukan melalui website dengan link matematika.fkip.unpas.ac.id, dan menggunakan aplikasi e-learning melalui video conference dengan Zoom. Pada webnya https://zoom.us, Zoom is the leader in modern enterprise video communications, with an easy, reliable cloud platform for video and audio conferencing, chat, and webinars. Kegiatan pelatihan, bimbingan, dan pendampingan dilakukan melalui 3 langkah.

Pertama, pelatihan, pembimbingan, dan pendampingan dalam menggunakan fiturfitur SPSS. Luaran yang diinginkan adalah para guru memahami, menguasai, dan terampil dalam menginput data sesuai tipe atau skala datanya.

Kedua, pelatihan, pembimbingan, dan pendampingan dalam mengumpulkan data sesuai rumusan masalah penelitian. Luaran yang diinginkan dari kegiatan ini adalah para guru memahami, menguasai, dan terampil dalam membuat instrumen penelitian.

Ketiga, pelatihan dalam menggunakan aplikasi e-learning. Kegiatan pelatihan ini meliputi penjelasan mengenai penggunaan aplikasi e-learning video conference yaitu Zoom. Luaran yang diinginkan adalah para guru bisa berdiskusi hasil pengumpulan data melalui video conference. 
Keempat, pelatihan dalam menganalisis dan menginterpretasi data penelitian. Luaran yang diinginkan dari kegiatan ini adalah para guru memahami, dan bisa menganalisis hasil output SPSS serta menginterpretasikkanya untuk bisa membuktikan hipotesis apa yang diterima sehingga bisa diambil kesimpulan dari hasil output itu.

Kelima, pelatihan dalam membuat artikel ilmiah. Luaran yang diharapkan adalah para guru memahami dan bisa membuat artikel ilmiah ilmiah.

Untuk mencapai solusi dan target luaran tersebut dibutuhkan aplikasi SPSS dan vicon (Zoom) sebagai beberapa produk jadi yang akan diimplementasikan pada PKM. Huda (2017), menjelaskan dalam tulisannya bahwa "Pada 1968, Norman H. Nie, C. Hadlai (Tex) Hull dan Dale H. Bent, tiga orang pemuda dari latar belakang profesional berbeda, memperkembangkan sistem perangkat halus yang berdasarkan gagasan statistika menggunakan untuk mengubah data mentah (RAW) menjadi informasi esensial untuk membuat keputusan. Sistem perangkat halus statistik revolusioner ini disebut SPSS, yang menjadi calon Statistical Package untuk Ilmu Pengetahuan Sosial". Namun seiring dengan semakin meningkatnya keuntungan SPSS dalam berbagai sektor umum yang komersial, dan organisasi akademis, maka kebutuhan SPSS kini digunakan untuk berbagai bidang keilmuan, khususnys dalam PKM ini.

Aplikasi e-learning melalui Zoom ini bisa digunakan melalui 3 cara, yaitu: 1) Melalui Web dengan link: https://zoom.us, 2) Melalui proses instal dengan mendownload master/aplikasi tersebut dan diinstal di PC, 3) Melalui smartphone yang bisa didownload aplikasinya di playstore. Dengan adanya berbagai cara menggunakan vicon ini, tentu akan mamberikan kemudahan bagi para guru dapat dengan cepat dan mudah mengakses $e$ learning melalui vicon tersebut.

\section{HASIL DAN PEMBAHASAN}

Program Kemitraan Masyarakat (PKM) Guru SMA di Kota dan Kabupaten Bandung dihadiri oleh 14 Guru Matematika dari MGMP Kota Bandung, dan 17 Guru Matematika dari MGMP Kabupaten Bandung. Kegiatan pelatihan ini dilakukan pada Tanggal 30 Mei 2018, bimbingan dan pendampingan dilakukan dari awal Bulan Juni sampai pertengahan Bulan Agustus 2018.

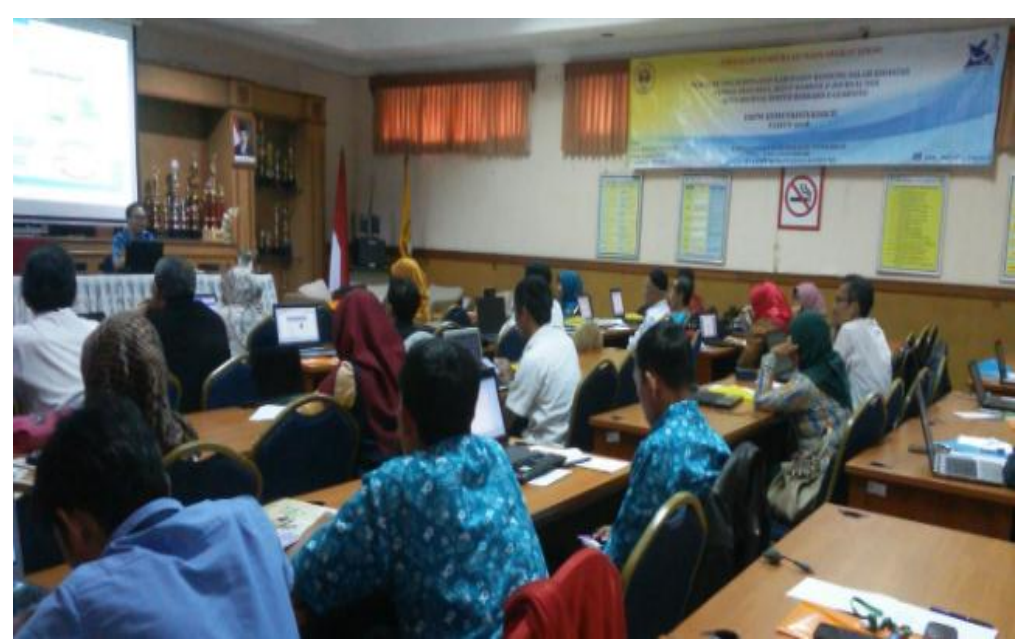

Gambar 1. Penyampaian Materi Pelatihan Menggunakan Fitur-Fitur SPSS, dan Mengumpulkan Data Sesuai Rumusan Masalah Penelitian 
Pelatihan dalam menggunakan fitur-fitur SPSS, dan pelatihan dalam mengumpulkan data sesuai rumusan masalah penelitian disampaikan oleh Bapak Thesa Kandaga, S.Si., M.Pd. Pada saat pelatihan tersebut, banyak para guru yang bertanya tentang penelitian, mereka merasa terpacu dengan adanya pelatihan ini. Terdapat perwakilan guru dari kedua MGMP yang menyampaikan pendapatnya bahwa mereka baru pertama kali lagi mendapatkan pelatihan seperti ini.

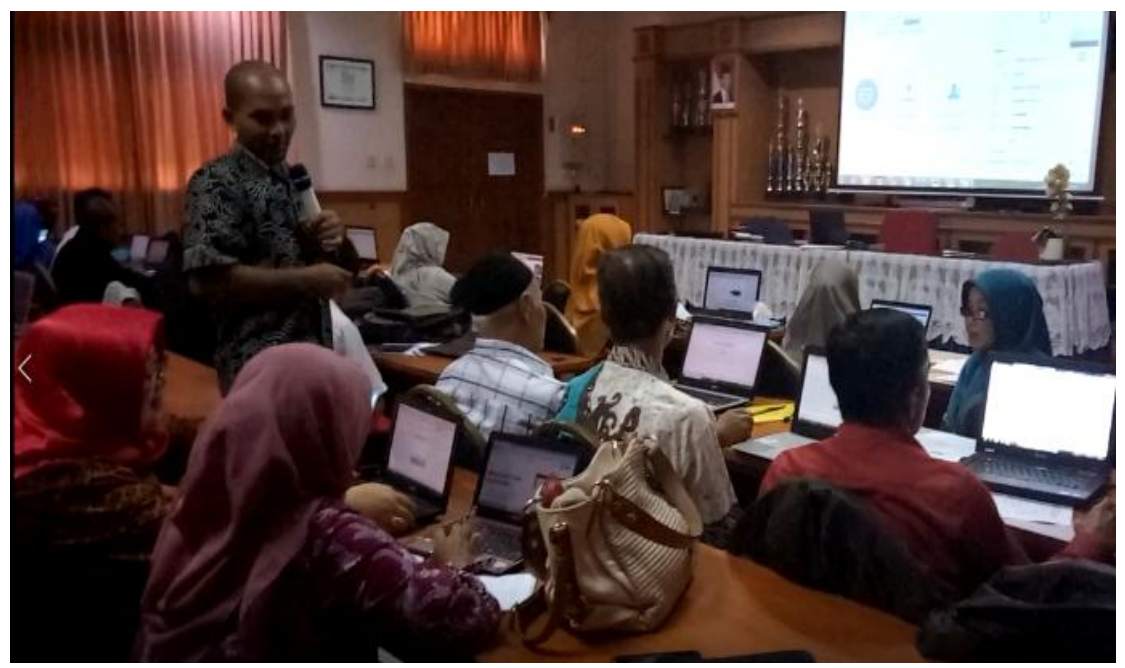

Gambar 2. Penyampaian Materi Pelatihan Aplikasi E-Learning

Pelatihan dalam menggunakan aplikasi e-learning disampaikan oleh Bapak Ali Imron S.T. yang merupakan instruktur dari South East Asean Ministry Open and Learning Center (SEAMOLEC). "SEAMOLEC adalah lembaga yang didirikan oleh Menteri Pendidikan seAsia Tenggara pada Tahun 1997", (Ariefyanto, 2013). Oleh karena itu, kami undang instruktur dari SEAMOLEC agar pembelajaran melalui Pendidikan Jarak Jauh (PJJ) dapat diterapakan dalam proses belajar mengajar oleh guru kepada murid umumnya dan dalam kegiatan PKM ini khususnya, terutama untuk pembimbingan dan pendampingan guru, sehingga proses belajar kita dapat dilakukan kapanpun dan dimanapun tanpa adanya batasan jarak dan waktu.

Salah satu PJJ yang disampaikan dalam pelatihan PKM adalah e-learning melalui Zoom. Zoom ini nantinya akan digunakan oleh kami dalam proses bimbingan dan pendampingan. Pemateri memberikan penjelasan tentang teori dan praktek cara menggunakan aplikasi tersebut, sehingga para guru dapat langsung mengimplementasikan cara menggunakan aplikasi tersebut.

Pembimbingan dan pendampingan berisi penyampaian materi-materi yang sudah disampaikan pada saat pelatihan untuk mengingatkan kembali materi yang sudah disampaikan yang dituangkan melalui web. Selain itu kami juga memperbaharui atau menambahkan materi terbaru yang diunggah melalui web, kemudian disana juga kami memberikan tugas dengan bantuan ada petunjuk dan langkah-langkah cara mengerjakannya. 


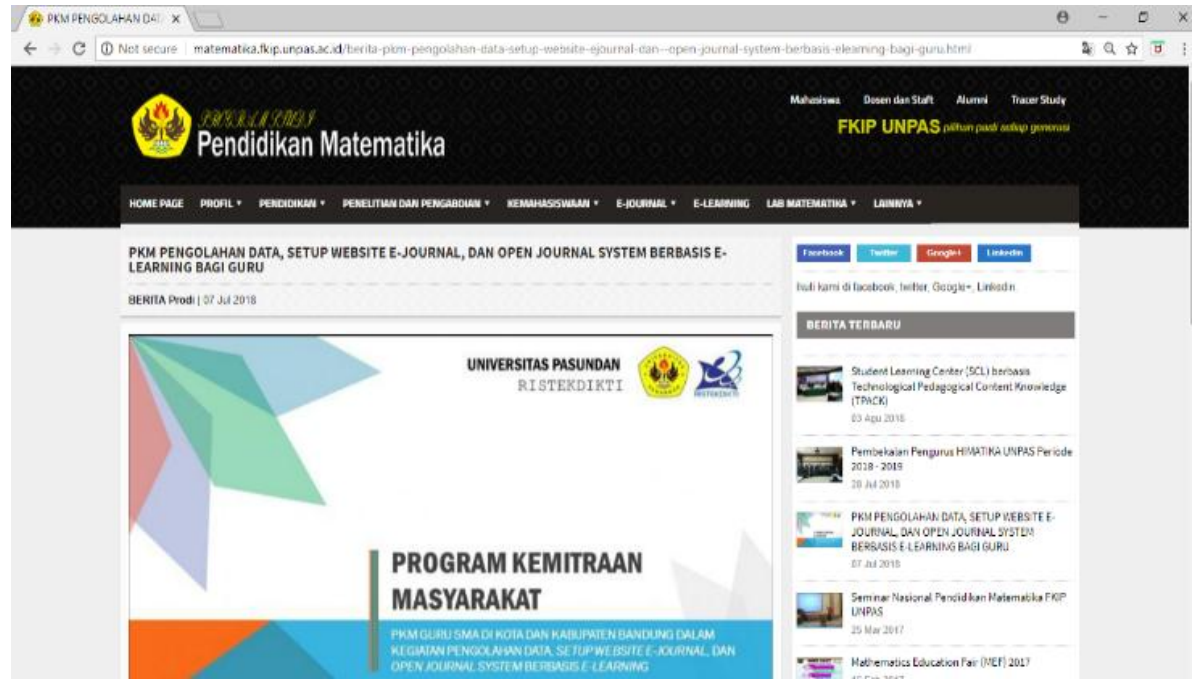

Gambar 3. Tampilan Website Pembimbingan dan Pendampingan

Tugas dikumpulkan melaui e-mail pkm_math@unpas.ac.id, setelah itu peserta akan mempresentasikan tugas melaui video ceonference. Melalui vicon, guru-guru akan dimbimbing dan didampingi pada saat menemukan tugas yang dianggap keliru sehingga tugasnya dapat diperbaiki dan tidak terjadi lagi melakukan kesalahan yang sama.

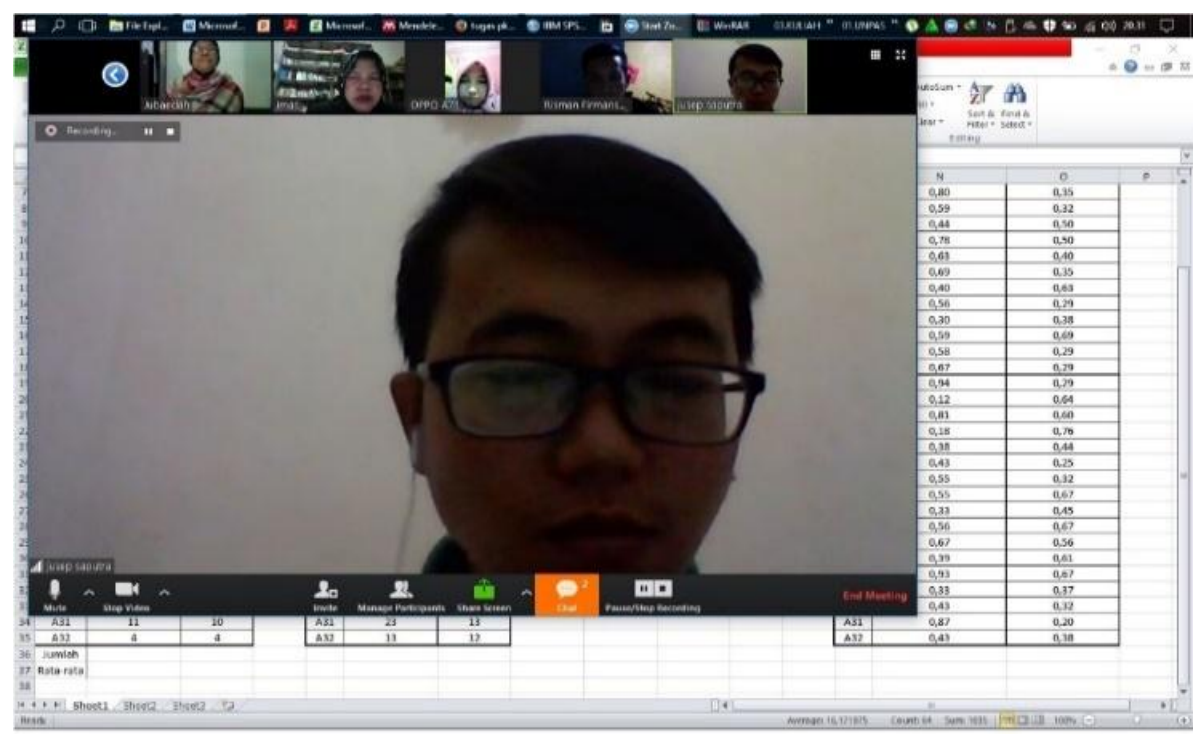

Gambar 4. Pembimbingan dan Pendampingan Melalui Melalui Video Conference

Setelah melakukan kegiatan PKM dalam menggunakan fitur-fitur SPSS, mengumpulkan data sesuai rumusan masalah penelitian, dan menggunakan aplikasi $e$ learning, kami memberikan angket mengenai kualitas pelaksanaan PKM dan angket selftest, untuk mengukur kemampuan peserta setelah mengikuti kegiatan, kami juga melakukan observasi terhadap kemampuan ICT para guru. Berikut ini ditampilkan diagram batang mengenai kualitas PKM untuk memudahkan pembaca dalam menilai kualitas pelatihan yang telah diselenggarakan pada Gambar 5 . 


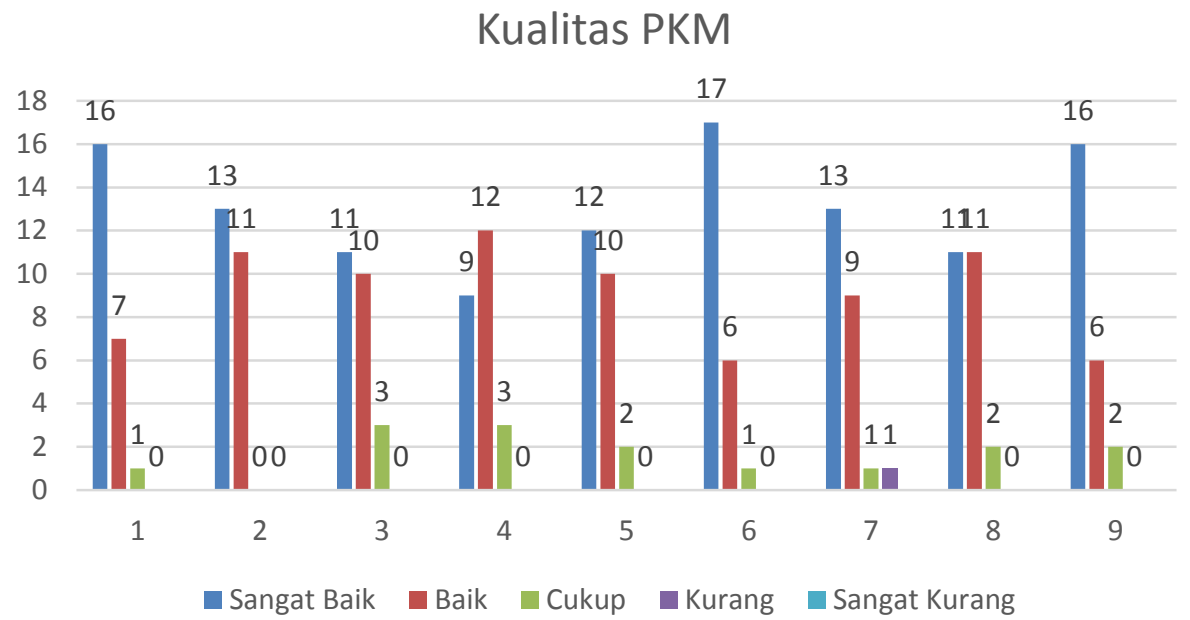

Gambar 5. Kualitas PKM dalam Membuat Rumusan Masalah, Intrumen Tes, Menggunakan Fitur-Fitur SPSS, dan Video Conference

Gambar 5 terdiri dari 9 pernyataan, yaitu (1) Tujuan dari PKM ini sangat membantu, (2) Materi dari PKM ini dapat menunjang profesi saya, (3) Materi pelatihan disajikan dengan baik, (4) Waktu pelaksanaan PKM ini disajikan dengan efektif dan efisien, (5) Metode yang digunakan dalam penyajian materi sudah baik, (6) Narasumber dibawakan oleh orang yang kompeten di bidangnya, (7) Tempat pelaksanaan PKM menunjang keberlangsungan acara dengan baik, (8) Alat dan media yang digunakan dalam PKM ini menunjang penyampaian materi dengan baik, (9) Pelayanan panitia PKM terhadap peserta sudah baik.

Gambar 5 mendeskripsikan bahwa dilihat secara visual melalui diagram batang menggambarkan bahwa hampir semua pernyataan para guru menyatakan bahwa kualitas PKM Sangat Baik, jadi secara keseluruhan para guru menilai sangat baik terhadap kegiatan PKM. Berikut ini ditampilkan juga diagram batang mengenai kualitas self-test, untuk memudahkan pembaca dalam membaca kemampuan peserta melalui diagram batang pada Gambar 6 .

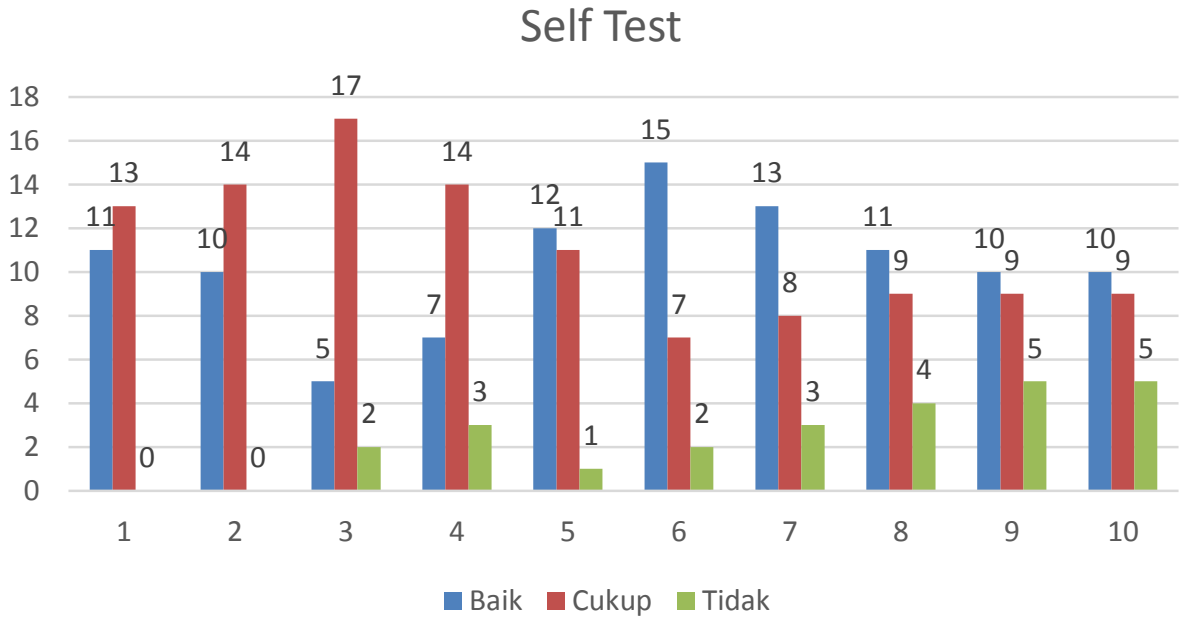

Gambar 6. Self-test Kemampuan Guru dalam Membuat Rumusan Masalah, Intrumen Tes, Menggunakan Fitur-Fitur SPSS, dan Video Conference 
Gambar 6 terdiri dari 10 pernyataan, yaitu (1) Memahami teknik perumusan masalah penelitian yang tepat, (2) Memahami teknik pembuatan desain instrumen tes, (3) Membuat rumusan masalah yang sesuai dengan topik penelitian yang direncanakan, (4) Membuat instumen penelitian yang sesuai dengan topik penelitian yang direncanakan, (5) Menggunakan komputer dalam pengolahan data statistik, (6) Mengetahui kegunaan SPSS, (7) Mampu melakukan input data ke dalam SPSS, (8) Memasang aplikasi video conference pada perangkat laptop maupun handphone, (9) Menggunakan WebEx/Zoom untuk komunikasi langsung via gambar, suara maupun camera/video, (10) Mengetahui fitur-fitur pada WebEx/Zoom.

Pernyataan (1) sampai (4) untuk mengukur kemampuan dalam memahami, menguasai, dan terampil dalam membuat instrumen penelitian. Hasil pengisian angket untuk keempat pernyataan diperoleh bahwa para guru menyatakan kemampuannya adalah cukup baik, dalam memahami, menguasai, dan terampil dalam membuat instrumen penelitian ada pada kategori cukup baik.

Pernyataan (5) sampai (7) untuk mengukur kemampuan dalam memahami, menguasai, dan terampil dalam menginput data sesuai tipe atau skala datanya. Hasil pengisian angket untuk ketiga pernyataan diperoleh bahwa kemampuannya adalah baik dalam menginput data sesuai tipe atau skala datanya.

Pernyataan (8) sampai (10) untuk mengukur kemampuan guru dalam menggunakan video conference untuk mendapatkan bimbingan dan pendampingan dalam mengerjakan tugas. Hasil analisis angket untuk ketiga pernyataan diperoleh bahwa kemampuannya adalah baik dalam menggunakan video conference untuk mendapatkan bimbingan dan pendampingan dalam mengerjakan tugas. Hal tersebut tentu menghasilkan hasil yang baik, seperti penelitian yang sudah dilakukan Saputra (2017, hlm. 77) bahwa aktivitas mahasiswa dalam mengikuti e-learning rata-ratanya naik dari kriteria kurang baik sampai menjadi baik

Pertemuan kedua dihadiri oleh 12 Guru Matematika dari Kota Bandung, dan 11 Guru Matematika dari Kabupaten Bandung. Jumlah tersebut menurun dibandingkan pada pertemuan 1 yang berjumlah 31 orang, hal ini dikarenakan pada saat yang bersamaan beberapa guru mempunyai acara lain dengan waktu yang bersamaan. Pertemuan kedua ini dilaksanakan pada Hari Rabu 15 Agustus 2018.

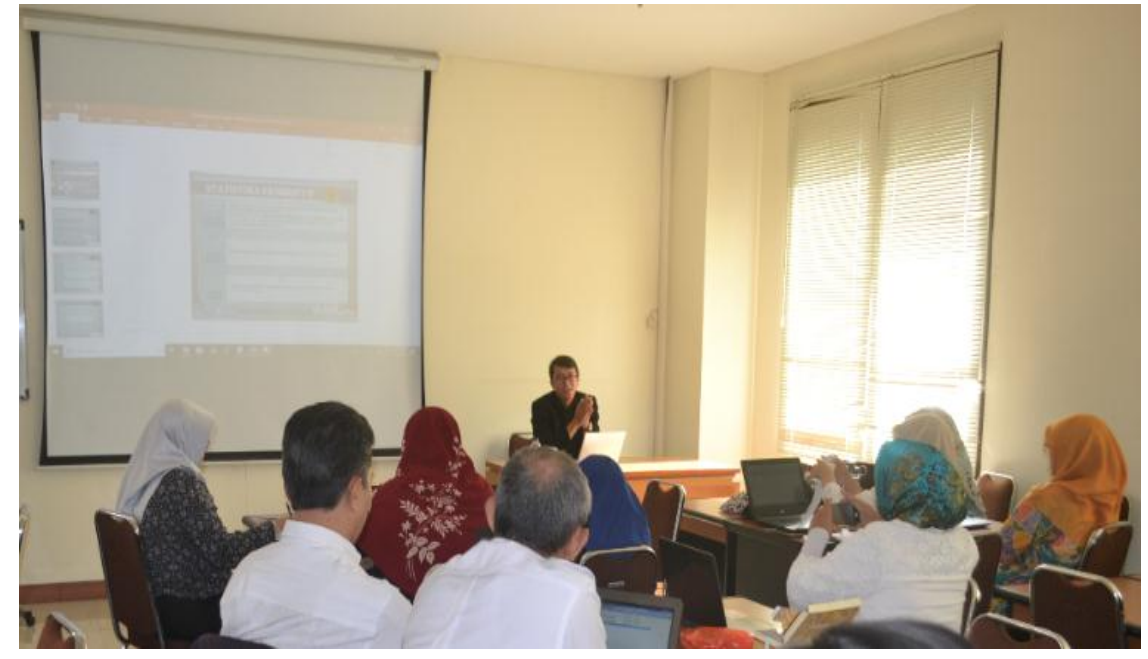

Gambar 7. Penyampaian Materi Pelatihan dalam Mengolah Data Penelitian dengan SPSS, dan Menganalisis, dan Menginterpretasi Data Penelitian Penelitian 
Pelatihan dalam mengolah data penelitian dengan SPSS, dan pelatihan dalam menganalisis, dan menginterpretasi data penelitian penelitian disampaikan oleh Bapak Jusep Saputra, M.Pd. Pada saat pelatihan tersebut, banyak para guru yang semangat dan antusias dalam mengikutinya, hal ini dikarenakan banyak guru baru perama kali menggunakan SPSS untuk mengolah data, akan tetapi ada juga yang sudah mengenal dan menggunakan SPSS semasa mereka kuliah tapi itupun dirasakan sudah cukup lama sehingga mereka lupa lagi cara menggunaknnya.

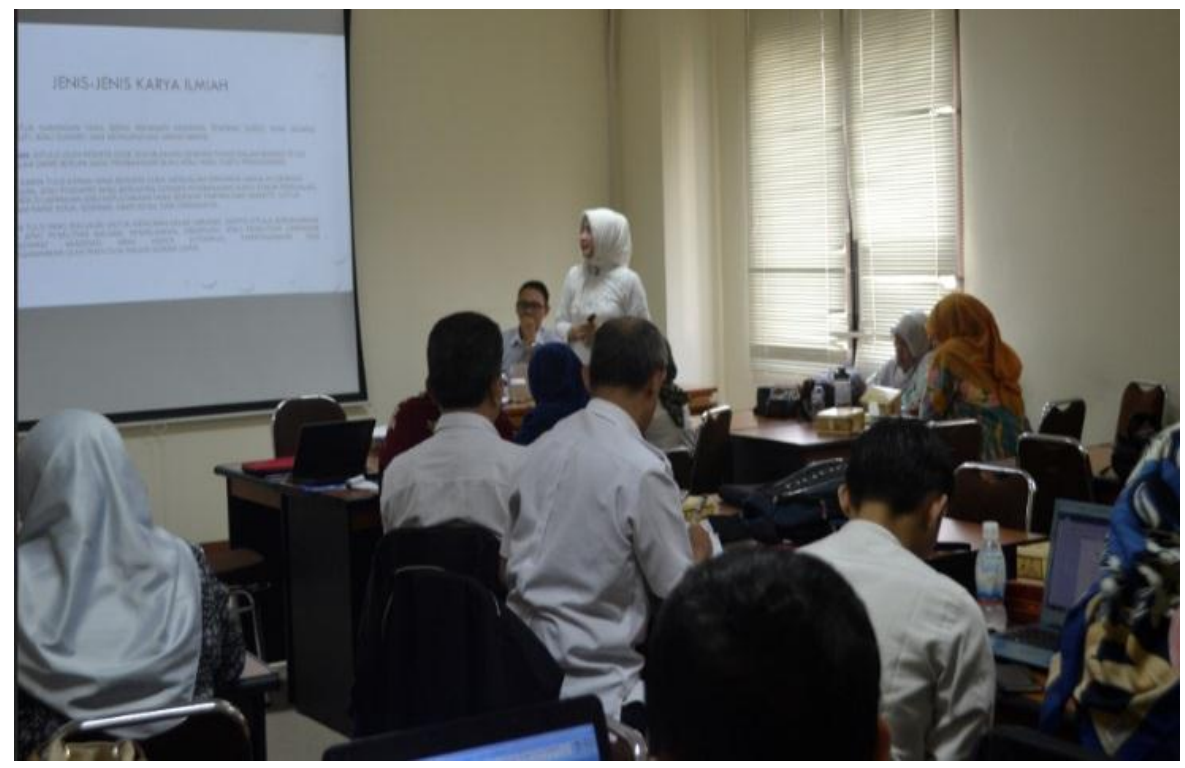

Gambar 8. Penyampaian Materi Pelatihan dalam Membuat Artikel Ilmiah

Kemudian dilanjutkan dengan pelatihan dalam membuat artikel ilmiah yang disampaikan oleh Prof. Dr. Hj. R. Poppy Yaniawatai, M.Pd., guru besar sekaligus Sekretaris Program Pascasarjana Program Studi Magister Pendidikan Matematika Universitas Pasundan. Pada pelatihan tersebut, beliau menjelaskan tentang definisi, ciriciri, jenis-jenis, tahapan penyusunan, sistematika penulisan karya ilmiah khususnya artikel.

Para guru menjadi lebih semangat dan termotivasi untuk membuat artikel setelah diberikan pelatihan tersebut, karena membuat artikel sendiri banyak sekali manfaatnya. Artikel yang dipublish berguna untuk menyebarkan ilmu yang sudah peroleh melalui penelitian dan kajian, dan juga memiliki reward untuk para guru dalam kenaikan pangkat dan golongan.

Setelah melakukan kegiatan pelatihan PKM pertemuan kedua kami menyebarkan angket mengenai kualitas pelatihan, dan angket self-test kemampuan dalam mengolahan data penelitian dengan SPSS; menganalisis, dan menginterpretasi data penelitian; serta membuat artikel ilmiah. Berikut ini ditampilkan diagram batang mengenai kualitas PKM untuk memudahkan pembaca dalam menilai kualitas pelatihan yang telah diselenggarakan pada Gambar 9. 


\section{Kualitas PKM}

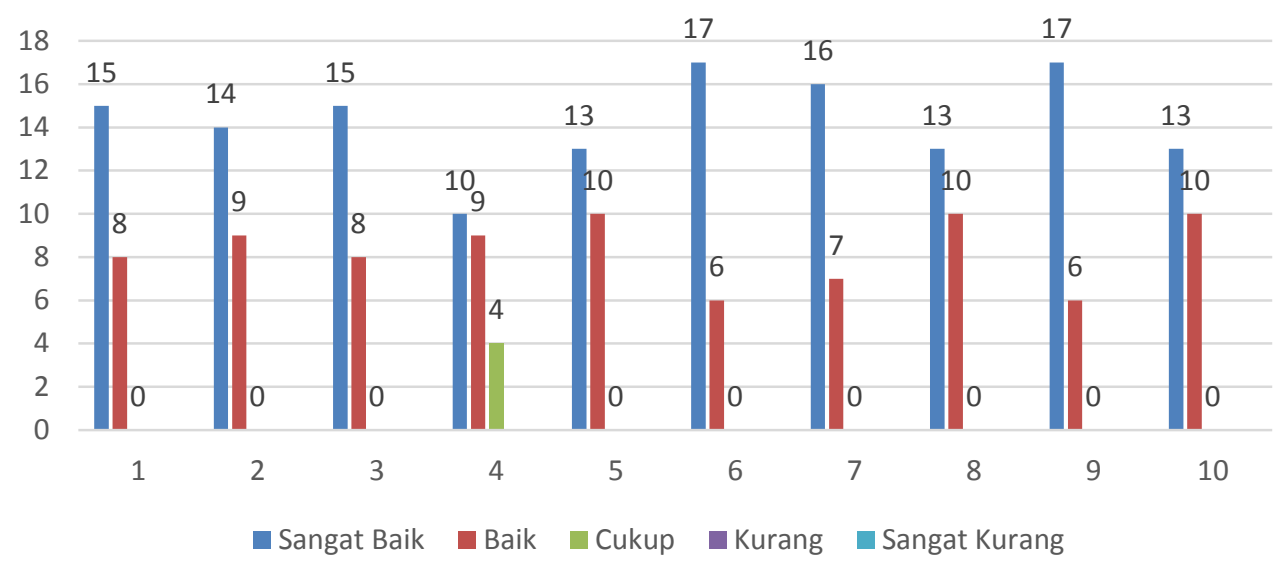

Gambar 9. Kualitas PKM dalam Mengolahan Data Penelitian Dengan SPSS; Menganalisis, dan Menginterpretasi Data Penelitian; serta Membuat Artikel Ilmiah

Gambar 9 terdiri dari 10 pernyataan, yaitu 9 pernyataan sama dengan yang terdapat pada Gambar 5 ditambah dengan 1 pernyataan baru yaitu "Makanan yang disediakan memuaskan". Gambar tersebut mendeskripsikan bahwa dilihat secara visual melalui diagram batang menggambarkan bahwa secara keseluruhan para guru menilai sangat baik terhadap kegiatan PKM. Sementara itu hasil self-test dengan topik mengolahan data penelitian dengan SPSS; menganalisis, dan menginterpretasi data penelitian; serta membuat artikel ilmiah tergambar dalam pada Gambar 10.

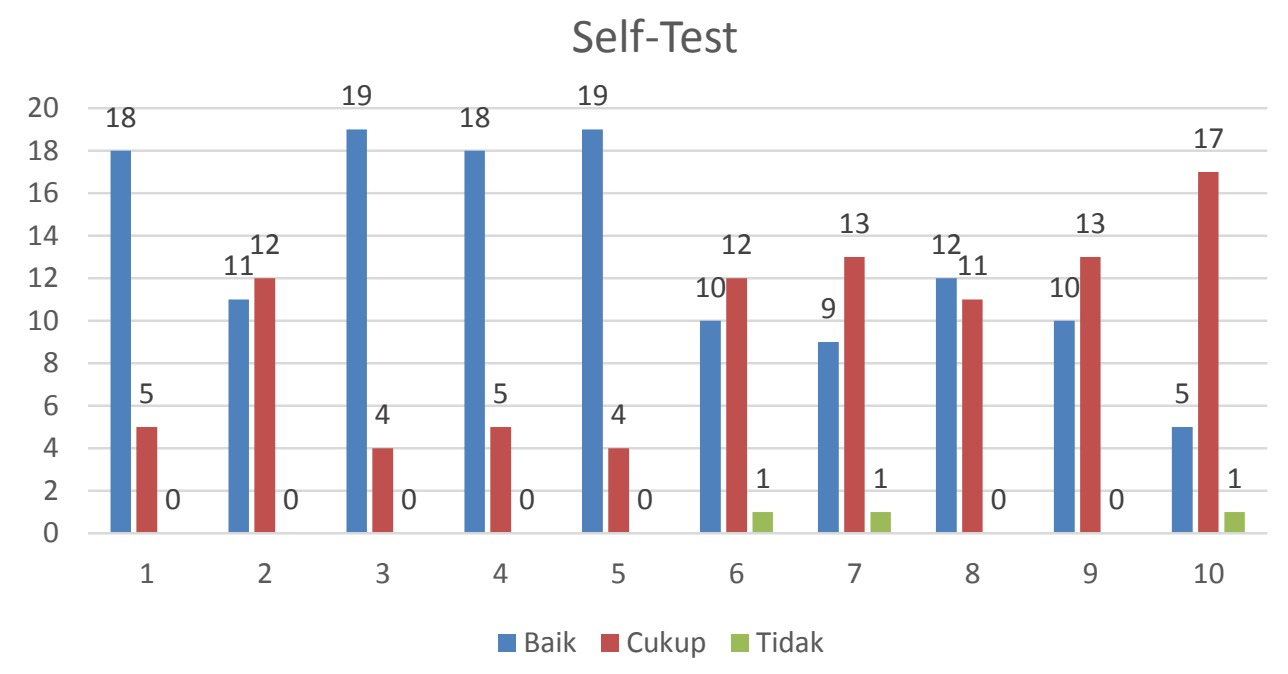

Gambar 10. Self-test Kemampuan Guru dalam Mengolahan Data Penelitian dengan SPSS; Menganalisis, dan Menginterpretasi Data Penelitian; Membuat Artikel Ilmiah

Gambar 6 terdiri dari 10 pernyataan, yaitu (1) Memahami perbedaan statistika deskriptif dan statistika inferensial, (2) Memahami perbedaan hipotesis penelitian (deskriptif, komparatif, asosiatif, regresi), (3) Memahami perbedaan ukuran-ukuran data (nominal, ordinal, scale=interval dan rasio), (4) Mampu menginput berbagai jenis data baik nominal, ordinal, maupun scale ke dalam SPSS sesuai hipotesis yang akan diuji, (5) Mampu mengolah data untuk menganalisis statistika deskriptif (rata-rata, median, 
modus, SD, varians, dll), (6) Mampu mengolah data untuk menganalisis statistika inferensial (menguji hipotesis: chi square, uji-t, wilcoxon, mann-whitney, dll), (7) Menganalisis hasil output SPSS dan menginterpretasikanya untuk bisa membuktikan hipotesis apa yang diterima sehingga bisa diambil kesimpulan, (8) Memahami tahapan penyusunan karya tulis ilmiah, (9) Memahami sistematika penulisan dan isi dari masingmasing komponen dalam artikel ilmiah, (10) Memahami dan bisa membuat artikel ilmiah ke depannya.

Pernyataan (1) sampai (7) untuk mengukur kemampuan dalam mengolahan data penelitian dengan SPSS; menganalisis, dan menginterpretasi data penelitian. Hasil pengisian angket untuk ketujuh pernyataan diperoleh bahwa para guru menyatakan kemampuannya adalah baik dalam mengolahan data penelitian dengan SPSS; menganalisis, dan menginterpretasi data penelitian. Pernyataan (8) sampai (10) untuk mengukur kemampuan dalam membuat artikel ilmiah. Hasil pengisian angket untuk ketiga pernyataan diperoleh bahwa para guru menyatakan kemampuannya adalah cukup baik dalam membuat artikel.

\section{SIMPULAN}

Berdasarkan analisis, hasil pembahasan yang sudah dianalisis pada uraian sebelumnya, diperoleh kesimpulan bahwa, (1) Kualitas PKM dalam membuat rumusan masalah, intrumen tes, menggunakan fitur-fitur SPSS, dan video conference yang dilakukan sudah sangat baik, (2) Kemampuan guru dalam memahami, menguasai, dan terampil dalam membuat instrumen penelitian baik tes atau non tes ada pada kategori cukup baik, (3) Kemampuan guru dalam menginput data sesuai tipe atau skala datanya ada pada kategori baik, (4) Kemampuan guru dalam menggunakan video conference untuk mendapatkan bimbingan dan pendampingan dalam mengerjakan tugas ada pada kategori baik, (5) Kemampuan guru dalam mengolahan data penelitian dengan SPSS; menganalisis, dan menginterpretasi data penelitian ada pada kategori baik, (6) Kemampuan dalam membuat artikel ilmiah ada pada kategori cukup baik.

\section{REFERENSI}

Andi. (2010). Mengolah data statistik hasil penelitian dengan SPSS 17.0.: Semarang: Wahana Komputer.

Ariefyanto, M. I. (2013). Ini model pendidikan jarak jauh di Indonesia. Retrieved November 20, 2017 from https://www.republika.co.id/berita/pendidikan/eduaction/13/03/19/ mjvwxj-ini-model-pendidikan-jarak-jauh-di-indonesia.

Mangindaan, E. E. (2009). Peraturan Menteri Negara Pendayagunaan Aparatur Negara dan Reformasi Birokrasi Nomor 16 Tahun 2009 Tentang Jabatan Fungsional Guru dan Angka Kreditnya. Jakarta: Menteri Negara Pendayagunaan Aparatur Negara dan Reformasi Birokrasi Republik Indonesia.

Saputra, J. (2015). Penggunaan Model Problem Based Learning Berbantuan E-Learning dalam Upaya Meningkatkan Kemampuan Pemecahan Masalah Matematis dan Dampaknya terhadap Kemandirian Belajar Mahasiswa. Pasundan Journal of Mathematics Education 5(2), 77-88. 
Saputra, J. (2017). Penggunaan model problem based learning berbantuan e-learning terhadap kemandirian belajar mahasiswa pada dimensi tiga. KALAMATIKA Jurnal Pendidikan Matematika, 2(2), 117-130.

Supianti, I. I. (2018). Pemanfataan teknologi informasi dan komunikasi (TIK) dalam pembelajaran matematika. MENDIDIK: Jurnal Kajian Pendidikan dan Pengajaran, 4(1), 63-70.

Yaniawati, P. (2010). E-learning: Alternatif pembelajaran kontemporer. Bandung: Arfino Raya. 